\section{Oral clonidine premedication decreases energy expenditure in human volunteers}

Hiroshi Takahashi MD, Toshiaki Nishikawa MD, Taro Mizutani MD, Fumi Handa MD

Purpose: Clonidine not only stops postoperative shivering and decreases oxygen consumption, but also decreases energy expenditure with or without a reduction in shivering during recovery from anaesthesia. It is important to see if clonidine decreases energy expenditure at rest since this may contribute to a postoperative decrease in energy expenditure. The authors tested the hypothesis that oral clonidine decreases energy expenditure at rest.

Methods: Twenty healthy male volunteers were randomly assigned to one of two groups. Ten volunteers received oral clonidine approximately $5 \mu \mathrm{ggg}^{-1}$ (clonidine group), while the remaining 10 volunteers received placebo (control group). Blood pressure, heart rate, body temperature at the tympanic membrane, sedation score graded from I (alert) to 5 (sleeping and difficult to be aroused by tactile stimulation) were measured before and at 30-min intervals for three hours after administration of clonidine or placebo. Measurements of energy expenditure and respiratory quotient were made with a head canopy system at one-minute intervals and averaged over $15 \mathrm{~min}$ before, and at 30,60,90,120, and $180 \mathrm{~min}$ after administration of clonidine or placebo.

Results: Sedation score increased from 1 to 3 (median) after clonidine administration. Energy expenditure decreased from $1452 \pm 225 \mathrm{kcal} \cdot 24 \mathrm{hr}^{-1}$ (mean \pm SD) at baseline to $1258 \pm 175 \mathrm{kcal} \cdot 24 \mathrm{hr}{ }^{-1}$ at $180 \mathrm{~min}$ after clonidine administration $(P<0.05)$.

Conclusion: This study suggests that oral clonidine at a dose of $5 \mu \mathrm{g} \cdot \mathrm{kg}^{-1}$ decreases energy expenditure at rest.

Objectif : En plus de prévenir le frisson postopératoire et de dimiruer la consommation en oxygène, la clonidine diminue la dépense énergétique au moment du réveil avec ou sans atténuation du frisson. Il est important de savoir si la clonidine diminue la dépense énergétique au repos étant donné que cet effet contribue a une baisse postopératoire de l'énergie dépensée.

Méthodes : Vingt volontaires en bonne santé de sexe masculin étaient assignés aléatoirement à deux groupes. Dix de ces volontaires recevaient environ $5 \mu \mathrm{g} \mathrm{kg}^{-1}$ de clonidine (groupe clonidine) alors que les autres recevaient un placebo (groupe contrôle). La pression artérielle, la fréquence cardiaque, la température corporelle et tympanique. le score de sédation coté sur une échelle de I (alerte) à 5 (endormi et difficile à réveiller par stimulation tactile) étaient notés avant et à 30 min d'intervalles pendant trois heures suivant l'administration de la clonidine ou du placebo. Les mesures de la dépense énergétique et du quotient respiratoire étaient réalisées à l'aide d'un casque et leurs moyennes calculées sur une pénode de 15 min avant et $30,60,90,120$ et 180 min après l'administration de la donidine ou du placebo.

Résultats : Le score de sédation a augmenté de I à 3 (médiane) après l'administration de la clonidine. La dépense énergétique a diminué de $1452 \pm 225 \mathrm{kcal} \cdot 24 \mathrm{~h}^{-1}$ (moyenne $\pm \mathrm{ET}$ ) initialement, à $1285 \pm 175$ $\mathrm{kcal} \cdot 24 \mathrm{~h}^{-1} 180 \mathrm{~min}$ après l'administration de la clonidine $(P<0,05)$.

Conclusion : Cette étude suggère qu'au repos, la clonidine orale $5 \mu \mathrm{g} \cdot \mathrm{kg}^{-1}$ diminue la dépense énergétique.

From the Department of Anaesthesiology, Institute of Clinical Medicine, University of Tsukuba.

Address correspondence to : Dr. Hiroshi Takahashi, Department of Anaesthesiology and Critical Care Medicine, Tsuchiura Kyodo General Hospital, 11-7 Manabeshinnmachi, Tsuchiura, Ibaraki 300, Japan. Phone: 011-81-298-23-3111; Fax: 011-81-298-23-1160; E-mail: hirotakn@intio.or.jp

Accepted for Publication Nuvember 23, 1996. 
$\mathrm{E}$ XPERIMENTALLY, clonidine reduces shivering 1 and oxygen consumption $\left(\mathrm{VO}_{2}\right)^{2}$ There is still controversy concerning this issue in clinical practice. Clonidine in a small dose of $30 \mu \mathrm{g} i v$ may be useful in suppressing shivering after epidural anaesthesia in parturients. ${ }^{3}$ Similarly, 200 or 300 $\mu \mathrm{g}$ oral clonidine given prior to and during coronary artery surgery reduced the incidence of postanaesthetic shivering, ${ }^{4}$ and an ip infusion of clonidine, $7 \mu \mathrm{g} \cdot \mathrm{kg}^{-1}$ over two hours, reduced the number of episodes of shivering after aortic surgery. ${ }^{5}$ In contrast, the infusion of 5 $\mu \mathrm{g} \cdot \mathrm{kg}^{-1}$ clonidine did not reduce the incidence of shivering after abdominal surgery. ${ }^{6}$ Although the underlying mechanism for suppression of postoperative $\mathrm{VO}_{2}$ by clonidine remains unknown, clonidine may decrease $\mathrm{VO}_{2}$ as a result of decreases in shivering and in circulating stress hormones during recovery from anaesthesia, or from reduction in subclinical shivering and basal metabolism under resting conditions.

Stimulation of the sympathetic nervous system associated with the liberation of norepinephrine and epinephrine increases the metabolic rate of various tissues of the body. ${ }^{7}$ The catecholamines exert a direct effect on muscle and liver cells, causing glycogenolysis. ${ }^{7}$ This metabolic alteration, together with other intracellular effects, increases cellular activity. Furthermore, sympathetic stimulation also has some influence on brown fat that produces nonshivering thermogenesis.?

Because clonidine inhibits norepinephrine release from sympathetic nerve terminals and thus lowers the plasma norepinephrine concentration, ${ }^{8-10}$ clonidine may decrease energy production not only during postoperative periods, but also at rest. However, there is no information regarding the effect of clonidine on resting metabolism in humans. The aim of this study is to determine whether oral clonidine medication affects metabolic rate in human volunteers.

\section{Methods}

After obtaining institutional approval and informed consent, 20 healthy men, aged from 22 to $29 \mathrm{yr}$ were selected for the study. No volunteers had any cardiopulmonary disorders, renal or hepatic dysfunction, past history of thyroid disease, dysautonomia, obesity exceeding standard body weight by $20 \%$, or were taking any medications affecting metabolic function.

Each volunteer was randomly assigned to one of two groups. Ten volunteers received approximately $5 \mu \mathrm{g} \cdot \mathrm{kg}^{-1}$ clonidine po (clonidine group), while the remaining 10 volunteers received placebo (control group). Because clonidine (Catapres, ${ }^{\circledR}$ Boehringer Ingelheim \& Tanabe, Kawanishi City, Hyogo, Japan) is available only in 75 or $150 \mu \mathrm{g}$ tablets in Japan, administered doses of clonidine were determined by choosing the closest doses calculated by multiplying $37.5 \mu \mathrm{g}$ (one half of a tablet) as a unit. The volunteers were minimally clothed, covered with a single unwarmed cotton blanket, ${ }^{11}$ and positioned supine with a pillow on a bed in a quiet room. The room temperature was controlled at $25^{\circ} \mathrm{C}$.

After overnight fasting, the study protocol started between 9 and $10 \mathrm{am}$. A $22 \mathrm{G}$ intravenous cannula was placed into the forearm cutaneous vein after local anaesthetic infiltration. Crystalloid solution (Soldem $3 \mathrm{~A} ;{ }^{\circledR} \mathrm{Na}$ $35 \mathrm{mEq} \cdot \mathrm{l}^{-1}$, K $20 \mathrm{mEq} \cdot \mathrm{l}^{-1}$, Cl $35 \mathrm{mEq} \cdot \mathrm{l}^{-1}$, lactate 20 $\mathrm{mEq} \cdot 1^{-1}$, glucose 4.3\%; Terumo, Tokyo, Japan) was thereafter infused at a rate of $0.7 \mathrm{ml} \cdot \mathrm{kg}^{-1} \cdot \mathrm{hr}^{-1}$ during the study. Arterial blood pressure and heart rate were measured at $\mathbf{3 0} \mathrm{min}$ intervals using an automatic blood pressure monitoring system (Listmini, ${ }^{\mathrm{TM}}$ Nippon Colin Co., Ltd., Tokyo). Core temperature was measured at the tympanic membrane with a thermocouple probe (Mona-Therm, ${ }^{\mathrm{TM}}$ St Louis, MO) connected to a thermometer (Model 8700, Mallinckrodt, St. Louis, MO). Sedation was evaluated by a blinded investigator and was graded by a scale of 1 to 5 ( 1 - alert; 2 -drowsy but easily aroused by verbal command to an alert state; 3 - sleeping and arousal by verbal command; 4 - sleeping not arousal by verbal stimuli, but arousal to a drowsy state by light tactile stimulation; and $\mathbf{5}$ - sleeping and difficult to be aroused by tactile stimulation). ${ }^{12}$

Energy expenditure and respiratory quotient were measured with a head canopy system (Deltatrac Metabolic Monitor, ${ }^{\text {TM }}$ Datex, Helsinki, Finland) which was calibrated before the beginning of the study in each subject. The accuracy of this method is $4 \pm 2 \%{ }^{13}$ Measurements of energy expenditure and respiratory quotient were performed automatically at one-minute intervals and averaged over $15 \mathrm{~min}$ periods before, and 30 (30-45 $\mathrm{min}), 60$ (60-75 min), 90 (90-105 min), $120(120-135 \mathrm{~min})$, and 180 (180-195 min) min after ingestion of clonidine or placebo. Basal metabolic rate (BMR) was calculated using the estimation of Harris and Benedict as follows: ${ }^{14}$

$\mathrm{BMR}\left(\mathrm{kcal} \cdot 24 \mathrm{hr}^{-1}\right)=66+13.8 \mathrm{~W}+5 \mathrm{H}-6.8 \mathrm{~A}$, where $\mathrm{W}$ is body weight $(\mathrm{kg}), \mathrm{H}$ body height $(\mathrm{cm})$, and $\mathrm{A}$ age (yr). Percent difference from BMR (\% Difference)

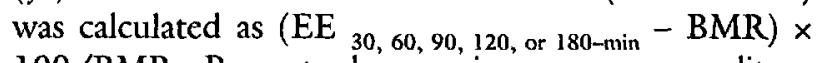
$100 / B M R$. Percent changes in energy expenditure

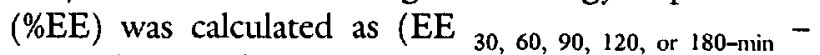
$\left.\mathrm{EE}_{\text {before }}\right) \times 100 / \mathrm{EE}_{\text {before }}$.

All data except sedation score between groups were analyzed by two-way analysis of variance (ANOVA) followed by unpaired Student's t-test. Analyses of consecutive haemodynamic and metabolic data in each group were made with analysis of variance for repeat- 
ed measures, and post hoc analysis was performed with Bonferroni/Dunn test. Mann-Whitney $U$ test and the Kruskal-Wallis test were used to compare sedation scores between groups and in each group, respectively. Values were expressed as means $\pm S D$. $P<0.05$ was considered to be statistically significant.

\section{Results}

There were no differences between groups with respect to age, body weight, height, body surface area, or BMR (Table I). The clonidine dose administered was $5.09 \pm 0.19 \mu \mathrm{g} \cdot \mathrm{kg}^{-1}$.

Baseline haemodynamic variables, body temperature, energy expenditure, and respiratory quotient were similar between groups (Table II). There were no differences between groups in mean arterial blood pressure, heart rate, and body temperature at any observation period, except in mean arterial blood pressure at 90 and $180 \mathrm{~min}$ and heart rate at $180 \mathrm{~min}$ after administration of clonidine or placebo (Table II). Respiratory quotient was lower in the clonidine group than in the control group at $30 \mathrm{~min}$ after clonidine administration $(P<0.05)$, but was within normal limits. Energy expenditure decreased from $1452 \pm 225$ $\mathrm{kcal} \cdot 24 \mathrm{hr}^{-1}$ at baseline to $1258 \pm 175 \mathrm{kcal} .24 \mathrm{hr}^{-1}$ at $180 \mathrm{~min}$ after clonidine administration, whereas it remained unchanged in the control group; values at 90-180 min in the clonidine group were lower than in the control group $(P<0.05)$. The reductions in $\% \mathrm{EE}$ attained a plateau at 120 min after clonidine administration. The \%EE values at $60-180 \mathrm{~min}$ in the clonidine group were lower than in the control group $(P<0.05)$. The $\%$ difference values were also greater from 90 to $180 \mathrm{~min}$ in the clonidine group than in the

TABLE I Demographic data

\begin{tabular}{lll}
\hline Grout & $\begin{array}{l}\text { Clonidine } \\
(n=10)\end{array}$ & $\begin{array}{l}\text { Control } \\
(n=10)\end{array}$ \\
\hline Age $(\mathrm{yr})$ & $26 \pm 2(22-29)$ & $26 \pm 2(22-29)$ \\
Weight $(\mathrm{kg})$ & $65 \pm 8(53-78)$ & $64 \pm 8(53-80)$ \\
Height $(\mathrm{cm})$ & $171 \pm 4(165-177)$ & $172 \pm 5(165-179)$ \\
Body Surface Area $\left(\mathrm{m}^{2}\right)$ & $1.76 \pm 0.12(1.58-1.95)$ & $1.75 \pm 0.13(1.58-1.98)$ \\
BMR $\left(\mathrm{kcal} \cdot 24 \mathrm{hr}^{-1}\right)$ & $1650 \pm 127(1430-1850)$ & $1633 \pm 133(1430-1890)$ \\
Clonidine $\left(\mu \mathrm{g} \cdot \mathrm{kg}^{-1}\right)$ & $5.09 \pm 0.19(4.80-5.36)$ & \\
\hline
\end{tabular}

Mean \pm SD (range)

Basal metabolic rate (BMR)

TABLE II Haemodynamic and metabolic variables and sedation score before and after clonidine $5 \mu \mathrm{g} \cdot \mathrm{kg}^{-1} \mathrm{po}$.

\begin{tabular}{|c|c|c|c|c|c|c|c|}
\hline & Group & Before & 30 min & $60 \mathrm{~min}$ & $90 \mathrm{~min}$ & $120 \min$ & $180 \min$ \\
\hline \multirow[t]{2}{*}{$\mathrm{MABP}(\mathrm{mmHg})$} & Clonidine & $85 \pm 10$ & $80 \pm 11$ & $77 \pm 13$ & $74 \pm 13^{\dagger}$ & $75 \pm 11$ & $74 \pm 11^{\dagger \dagger}$ \\
\hline & Control & $84 \pm 6$ & $83 \pm 6$ & $83 \pm 9$ & $85 \pm 9$ & $83 \pm 9$ & $88 \pm 9$ \\
\hline \multirow[t]{2}{*}{$\mathrm{HR}$ (bpm) } & Clonidine & $58 \pm 7$ & $51 \pm 6$ & $49 \pm 7$ & $49 \pm 6$ & $50 \pm 8$ & $51 \pm 7^{\dagger}$ \\
\hline & Control & $58 \pm 5$ & $56 \pm 8$ & $55 \pm 9$ & $53 \pm 6$ & $54 \pm 6$ & $59 \pm 8$ \\
\hline \multirow[t]{2}{*}{$\operatorname{Temp}\left({ }^{\circ} \mathrm{C}\right)$} & Clonidine & $36.5 \pm 0.3$ & $36.4 \pm 0.3$ & $36.3 \pm 0.3$ & $36.3 \pm 0.3$ & $36.4 \pm 0.3$ & $36.4 \pm 0.3$ \\
\hline & Control & $36.6 \pm 0.2$ & $36.5 \pm 0.3$ & $36.4 \pm 0.3$ & $36.5 \pm 0.2$ & $36.4 \pm 0.3$ & $36.5 \pm 0.3$ \\
\hline \multirow[t]{2}{*}{$\mathrm{EE}\left(\mathrm{kccal} \cdot 24 \mathrm{hr} r^{-1}\right)$} & Clonidine & $1452 \pm 225$ & $1327 \pm 186$ & $1279 \pm 174$ & $1281 \pm 172^{\dagger}$ & $1258 \pm 202^{\dagger}$ & $1258 \pm 175^{\dagger}$ \\
\hline & Control & $1453 \pm 228$ & $1413 \pm 186$ & $1431 \pm 174$ & $1447 \pm 173$ & $1469 \pm 212$ & $1479 \pm 211$ \\
\hline \multirow[t]{2}{*}{$\mathrm{RQ}$} & Clonidine & $0.83 \pm 0.05$ & $0.83 \pm 0.03^{t t}$ & $0.89 \pm 0.05$ & $0.88 \pm 0.04$ & $0.87 \pm 0.03$ & $0.88 \pm 0.04$ \\
\hline & Control & $0.86 \pm 0.03$ & $0.88 \pm 0.03$ & $0.90 \pm 0.05$ & $0.88 \pm 0.06$ & $0.91 \pm 0.06$ & $0.88 \pm 0.06$ \\
\hline \multirow[t]{2}{*}{ Sedation score } & Clonidine & 1.0 & $2.0^{*}$ & $2.5^{*}$ & $3.0 * \dagger$ & $3.0^{*+1}$ & $2.5 * t \dagger$ \\
\hline & Control & 1.0 & $2.0^{\star}$ & $2.0^{*}$ & $2.0^{\star}$ & $1.5^{\star}$ & $1.0^{\star}$ \\
\hline \multirow[t]{2}{*}{$\% \mathrm{EE}^{\mathrm{a}}$} & Clonidine & & $-7.6 \pm 5.1$ & $-10.7 \pm 7.0^{\dagger \dagger}$ & $-10.8 \pm 9.4^{\dagger \dagger}$ & $-1.2 .4 \pm 12.0^{\dagger}$ & $-12.3 \pm 11.0^{\dagger \dagger}$ \\
\hline & Control & & $-2.7 \pm 5.6$ & $0.4 \pm 6.2$ & $0.72 \pm 5.8$ & $0.77 \pm 8.4$ & $1.4 \pm 5.6$ \\
\hline \multirow[t]{2}{*}{ \% Difference $E^{b}$} & Clonidine & $-10 \pm 12$ & $-17 \pm 11$ & $-20 \pm 10$ & $-21+9^{\dagger}$ & $-22 \pm 11^{\dagger}$ & $-22 \pm 8^{t}$ \\
\hline & Control & $-12 \pm 11$ & $-14 \pm 9$ & $-12 \pm 8$ & $-11 \pm 9$ & $-11 \pm 9$ & $-11 \pm 11$ \\
\hline
\end{tabular}

Mean \pm SD or median. MABP - mean arterial blood pressure; HR - heart rate; EE - energy expenditurc; RQ - respiratory quotient. $\% \mathrm{EE}^{\mathrm{a}}=\left(\mathrm{EE}_{\mathrm{x}}-\mathrm{EE}_{\text {before }}\right) \times 100 / \mathrm{EE}_{\text {before }} \%$ difference $\mathrm{EE}^{\mathrm{b}}=\left(\mathrm{EE}_{\mathrm{x}}-\mathrm{BMR}\right) \times 100 / \mathrm{BMR}$

$E E_{x}$ is energy expenditure at $30,60,90,120$, or 180 min after treatment.

${ }^{\star} P<0.05$ vs before treatment. ${ }^{\dagger} P<0.05$ vs control. ${ }^{{ }^{t} P} P<0.01$ vs control. 
control group $(P<0.05$, Table II). Although increases in sedation scores were noted from 30 to $180 \mathrm{~min}$ after clonidine or placebo $(P<0.05)$, sedation scores were higher from 90 to $180 \mathrm{~min}$ in the clonidine group than in the control group $(P<0.05)$.

\section{Discussion}

The present results show that the energy expenditure decreased 90 to $180 \mathrm{~min}$ after oral clonidine in a dose of $5.09 \pm 0.19 \mu \mathrm{g}^{\mathrm{kg}} \mathrm{kg}^{-1}$ in healthy volunteers and this was associated with increases in sedation scores.

Energy expenditure is affected by food, age, sex, circulating concentrations of thyroid hormones, epinephrine and norepinephrine, environmental temperature, emotional state, and muscular exertion before and during measurement. ${ }^{15}$ The present study was performed in fasting healthy, young men under resting conditions. The maximum sedative effect of clonidine appeared 90 to $120 \mathrm{~min}$ after clonidine administration as reported previously. 16,17 We had speculated that the sedative effect of clonidine would decrease energy expenditure at rest, because metabolic rate decreases by 10 to $15 \%$ during sleep due to decreased skeletal musculature tone and decreased sympathetic nervous system activity? This assumption appears to have been reasonable, since the maximum decrease in energy expenditure after clonidine administration was $12 \%$ in the present study.

Our results show that clonidine decreased energy expenditure in subjects without shivering. In previous studies, energy expenditure decreased regardless of the presence of shivering during recovery from anaesthesia. ${ }^{5,6}$ Similarly, clonidine attenuated the increase in $\mathrm{VO}_{2}$ and $\mathrm{VCO}_{2}$ associated with recovery from anaesthesia, ${ }^{6,18}$ which was associated with ${ }^{18}$ and without ${ }^{6}$ a reduction in shivering. According to a recent study, clonidine may impair central control of thermoregulation, thus reducing the thresholds for vasoconstriction and shivering. ${ }^{19}$ Interestingly, even a small bolus dose of clonidine $75 \mu \mathrm{g} i \mathrm{p}$ decreased $\mathrm{VO}_{2}$ before and after the occurrence of shivering. ${ }^{19}$ This finding shows that clonidine can decrease $\mathrm{VO}_{2}$ even if it does not stop shivering.

Clonidine inhibits thyroid function via an $\alpha_{2}$-adrenoceptor $^{20}$ directly or indirectly, because clonidine decreases plasma norepinephrine concentration, ${ }^{8-10}$ which stimulates thyroid hormone secretion by activating the adrenoceptor ${ }^{21}$ In addition, clonidine suppresses sympathoadrenal outflow, ${ }^{8,22}$ and stress-induced adrenocorticotropic hormone and cortisol release ${ }^{23}$ It is likely that clonidine decreases energy expenditure through suppressing stress hormone release, although clonidine stimulates growth hormone secretion, ${ }^{24}$ and increases serum glucose due to inhibition of insulin release. ${ }^{25,26}$
Although we did not measure hormone concentrations during the experiment, a furure study involving such measurements would be worthwhile considering the diffuse action of clonidine on the hormonal milieu as noted above.

In summary, oral clonidine in a dose of $5 \mu \mathrm{g} \cdot \mathrm{kg}^{-1}$ decreases energy expenditure at rest in healthy volunteers.

\section{Acknowledgments}

The authors thank Boehringer Ingelheim \& Tanabe Company for a generous donation of clonidine.

\section{References}

1 Marshall $H W$, Stoner HB. Catecholaminergic $\alpha$-receptors and shivering in the rat. J Physiol (Lond) 1979; 292: 27-34.

2 Maxwell GM. The effects of 2-(2,6-dichlorphenylamine)-2-imidasoline hydrochloride (Catapres $®$ ) upon the systemic and coronary haemodynamics and metabolism of intact dogs. Arch Int Pharmacodyn 1969; 181: 7-14

3 Capogna $G$, Celleno D. I.V. clonidine for post-extradural shivering in parturients: a preliminary study. $\mathrm{Br} \mathrm{J}$ Anaesth 1993; 71: 294-5.

4 Flacke JW, Bloor BC, Flacke WE, et al. Reduced narcotic requirement by clonidine with improved hemody. namic and adrenergic stability in patients undergoing coronary bypass surgery. Anesthesiology 1987; 67: 11-9.

5 Quintin $L$, Roudot $F$, Roux $C$, et al. Effect of clonidine on the circulation and vasoactive hormones after aortic surgery. Br J Anaesth 1991; 66: 108-15.

6 Quintin L, Viale JP, Annat G, et al. Oxygen uptake after major abdominal surgery: effect of clonidine. Anesthesiology 1991; 74: 236-41.

7 Guyton AC. Energetics and metabolic rate. In: Textbook of Medical Physiology, 8th ed. Philadelphia: WB Saunders Company, 1991: 789-96.

8 Veith RC, Best JD, Halter JB. Dose-dependent suppression of norepinephrine appearance rate in plasma by clonidine in man. J Clin Endocrinol Metab 1984; 59 : 151-5.

9 Kooner JS, Birch R, Frankel HL, Peart WS, Mathias CJ. Hemodynamic and neurohormonal effects of clonidine in patients with preganglionic and postganglionic sympathetic lesions. Evidence for a central sympatholytic action. Circulation 1991; 84: 75-83.

10 Pouttu J, Tuominen M, Scheinin M, Rosenberg PH. Effects of oral clonidine premedication on concentrations of cortisol and monoamine neurotransmitters and their metabolites in cerebrospinal fluid and plasma. Acta Anaesthesiol Scand 1989; 33: 137-41. 
11 Sessler DI, Schroeder M. Heat loss in humans covered with cotton hospital blankets. Anesth Analg 1993; 77: 73-7.

12 Segal IS, Jarvis DJ, Duncan SR, White PF, Maze M. Clinical efficacy of oral-transdermal clonidine combinations during the perioperative period. Anesthesiology 1991; 74: 220-5.

13 Takala J, Keinänen $O$, Väisünen $P$, Kari A. Measurement of gas exchange in intensive care: Laboratory and clinical validation of a new device. Crit Care Med 1989; 17: 1041-7.

14 Rosenberg $I H$. Nutrition and nutritional requirements. In: Harrison's Principles of Internal Medicine, 13th ed. New York: McGraw-Hill, Inc., 1994: 437-40.

15 Ganong WF. Energy balance, metabolism, \& nutrition. In: Review of Medical Physiology, 17th ed. Connecticut: Prentice-Hall International Inc., 1995: 255-89.

16 Davies DS, Wing LMH, Reid JL, Neill E, Tippett $P$, Dollery CT. Pharmacokinetics and concentration-effect relationships of intravenous and oral clonidine. Clin Pharmacol Ther 1977; 21: 593-601.

17 Reid JL. The clinical pharmacological of clonidine and related central antihypertensive agents. $\mathrm{Br}$ J Clin Pharmacol 1981; 12: 295-302.

18 Delaunay L, Bonnet F, Duvaldestin P. Clonidine decreases postoperative oxygen consumption in patients recovering from general anaesthesia. Br J Anaesth 1991; 67: $397-401$.

19 Delaunay L, Bonnet F, Liu N, Beydon L, Catoive P, Sessler DI. Clonidine comparably decreases the thermoregulatory thresholds for vasoconstriction and shivering in humans. Anesthesiology 1993; 79:470-4.

20 Muraki T, Nakaki T, Kato R. Predominance of $\alpha_{2}$-adrenoceptors in porcine thyroid: biochemical and pharmacological correlations. Endocrinology 1984; 114: 1645-51

21 Melander A, Ranklev E, Sundler F, Westgren $U$. Beta ${ }_{2}{ }^{-}$ adrenergic stimulation of thyroid hormone secretion. Endocrinology 1975; 97: 332-6.

22 Mertes N, Goeters C, Kubmann M, Zander JF. Postoperative $\alpha_{2}$-adrenergic stimulation attenuates protein catabolism. Anesth Analg 1996; 82: 258-63.

23 Masala A, Satta $G$, Alagna $S$, et al. Effect of clonidine on stress-induced cortisol release in man during surgery. Pharmacological Research Communications 1985; 17: 293-8.

24 Grossman $A$, Weerasuriya $K$, Al-Damluji $S$, Turner $P$, Besser GM. Alpha ${ }_{2}$-adrenoceptor agonists stimulate growth hormone secretion but have no acute effects on plasma cortisol under basal conditions. Horm Res 1987; 25: 65-71.

25 Metz SA, Halter JB, Robertson RP. Induction of defective insulin secretion and impaired glucose tolerance by clonidine. Selective stimulation of metabolic alphaadrenergic pathways. Diabetes 1978; 27: 554-62.

26 Joffe BI, Haitas B, Edelstein D, et al. Clonidine and the hormonal responses to graded exercise in healthy subjects. Horm Res 1986; 23: 136-41. 